\title{
OLIVE AND AVOCADO OILS AND THEIR BLEND: EVALUATION AND UTILIZATION IN SOME FOODS Sharara, Magda S. ${ }^{*}$ and Rehab A. E. Mostafa ${ }^{* *}$ \\ ${ }^{*}$ Food Science and Technology Dept., Fac.of Agric., Alexandria. Univ., 21545, El- Shatby, Alexandria - Egypt. \\ ${ }^{\star *}$ Special Food Res., Dept., Food Technology Inst.,(ARC) Sabahia, Alex, Egypt
}

\begin{abstract}
Olive oil $(\mathrm{OO})$ and avocado oil $(\mathrm{AO})$ along with their blend $(\mathrm{OAB})$ at 1:1 ratio were evaluated in terms of physicochemical properties, polyphenols, oil classes, fatty acids composition, stability and antioxidant activity. Utility of these oils in making cake and oil/butter blend was also investigated. No significant differences could be traced among $\mathrm{OO}, \mathrm{AO}$ and $\mathrm{OAB}$ with respect to saponification value and specific absorbance $\left(\mathrm{K}_{232}\right)$. In contrast, refractive index, specific gravity, free fatty acids iodine value, peroxide value, specific absorbance ( $\mathrm{K}_{270}$ ) and three colour values assessed by Lovibond Tintometer, exhibited significant differences among the aforementioned oils. Fatty acids composition revealed that $A O$ had the highest content of $\mathrm{C}_{16: 0}(18.63 \%)$, followed by $\mathrm{OAB}(15.23 \%)$ while $\mathrm{OO}$ tailed behind $(13.15 \%)$. The highest content $(4.01 \%)$ of $\mathrm{C}_{18: 0}$ was belonging to $\mathrm{OO}$, while $\mathrm{OAB}$ had $(3.26 \%)$ and $\mathrm{AO}$ exhibited $(2.42 \%)$. Content of unsaturated fatty acids of the three oils was higher than their counter parts of saturated ones. The $\mathrm{OO}$ possessed the highest content of polyphenols, while AO had the least content but it possessed the highest content of cholorophyll. Direct relationship could be figured out between content of polyphenols and antioxidant activity $(68.2 \%, 61.0 \%$ and $53.7 \%$ for $\mathrm{OO}, \mathrm{OAB}$ and $\mathrm{AO}$, respectively). Moreover, polyphenols were separated by TLC into nine bands in $\mathrm{OO}$ and OAB while six bands were found in AO. Oil classes which were separated by TLC indicated that triacylglycerols, diacylglycerols, monoacylglycerols and polar compounds were the most abundant compounds in studied oils. Incorporation of $\mathrm{OO}, \mathrm{AO}$ and $\mathrm{OAB}$ in formulation of carrot cake and oil/butter blend was found to be quite accepted by panelists.

Keywords: Olive oil, Avocado oil, Polyphenols, Antioxidant activity, Fatty acids composition, Oil classes.
\end{abstract}

\section{INTRODUCTION}

Vegetable oils are the major source of edible lipids which are consumed in the world. They are extracted either from the endosperm of the oil seeds or from the pericarp of oil fruits, mainly palm and olive. Another important oil fruit is avocado (Persea americana Mill.). Avocado is mainly grown in Mexico, the USA and Indonesia (Anonymous, 2000). However, the cultivation of avocado is expanding into some non-traditional localities, such as Sicily and Calabria in the Mediterranean area (Frega et al., 1990). Avocado is also grown in Turkey, and plantations have rapidly expanded during the past decade. In Egypt avocado is grown in a small quantities in scattered areas. From the nutritional point of view, avocado is an important and high caloric fruit. Indeed its high content of unsaturated fatty acids is one of its distinguishing characteristics. Moreover, avocado is rich in vitamin $\mathrm{E}$, ascorbic acid, vitamin $\mathrm{B}_{6}, \beta$-carotene, and potassium (Bergh, 1992). 
Avocado oil is suitable for preventing the human body from accumulating the undesirable low-density lipoprotein (LDL) cholesterol and promotes healthy high-density lipoprotein (HDL) cholesterol accumulation, which is beneficial to the heart. Studies also prove that the presence of $\beta$ sitosterol in avocado oil helps in relieving the symptoms of prostate enlargement amongst men, besides lowering the cholesterol build-up(Chan, 2005). Cold-pressed avocado oil is relatively new in culinary circles, and its production volume is relatively small compared with other oils, with approximately 2000 tons/year. New Zealand, Mexico, Chile, United States and South Africa are among the main avocado oil producers. Its significant production, commercialization and marketing are only occurring in the twentyfirst century, and limited published information still exists on this product . Avocado oil has the advantage, as with olive oil, which can be obtained from the fruit by means of a cold extraction method, which is an easy, low cost technology that allows maintaining in the oil significant amounts of the bioactive phytochemicals present in the fruit. The concentration of sterols in avocado oil is around $3.3 \mathrm{mg} / \mathrm{g}$ oil (Woolf et al., 2008). Plant sterols, or phytosterols, are triterpene compounds, similar in structure to cholesterol, that are found in plants, can be divided into three main classes: 4desmethylsterols, 4-methylsterols, and 4,4-dimethylsterols (triterpene alcohols). Many studies demonstrated that 4-desmethylsterols have healthy benefits, such as the decrease in the LDL cholesterol. Also, they possess anticancer, anti-inflammatory, antiatherogenic, and antioxidative activities (Berger et al., 2004 and Alvarenga \& Ferro,2005). Regarding 4,4dimethylsterols, although some healthy properties have been described for some of them, they have been mainly used to oil identification purposes (Azadmard-Damirchi et al., 2005). The phenolic compounds of olive oil have multiple biological effects, including antioxidant activity (Gordon et al., 2001), nutritional properties (Galli and Visioli, 1999) and sensory quality (Angerosa at al., 2000). Moreover, they have been suggested to play a preventive role in the development of cancer and heart disease (Uccella, 2001). The use of oil blends to be consumed either directly or as an ingredient in many foodstuffs is much extended in many countries. The consideration of olive oil as a healthy product, together with its good organoleptic properties, makes it one of the most common ingredients of this kind of blends. The reasons for mixing olive oil with others are not only economical, the production of good olive oil is labour intensive and the resulting product is usually more expensive than other vegetable oils, but also nutritional. It is clear from the composition of vegetable oils, that no single oil, even olive oil, in realistic portion sizes (up to $33 \mathrm{~g} /$ day), meets all the oil nutritional requirements of essential fatty acids and vitamins (Darmon et al., 2006).

The present study aimed to utilize the avocado oil in food production as a new oil rich in unsaturated fatty acids especially oleic acid. Moreover it is similar in composition and most properties to olive oil, which provides an opportunity to be used in food purposes either alone or mixed with olive oil. 


\section{MATERIALS AND METHODS}

Materials:-

Extra virgin avocado oil (AO) (Cold pressed, Grove, New Zealand avocado) and extra virgin olive oil (OO) (Cold pressed, SPARTA Gold, Greece) were purchased from Alexandria market, Egypt. A blend of the aforementioned two oils $(\mathrm{OAB})$ was prepared at a ratio of $1: 1$ to study characteristics and composition of the three oils under investigation.

Methods:-

Analytical methods:-

Oil characteristics and composition:-

Colour:-

Colour of oils was determined using Lovibond Schofield Tintometer and expressed as blue, yellow and red colour fractions according to (Makinney and Little, 1962).

Identity characteristics:-

The specific gravity at $25^{\circ} \mathrm{C}$, refractive index at $25^{\circ} \mathrm{C}$ and iodine absorption number were determined according to AOAC (1998). Saponification value was determined according to Egan et al. (1987).

Peroxide value (PV):-

It was determined according to the method of AOAC (1998) and expressed in milliequivalent of active oxygen per kilogram of oil (meq $\mathrm{O}_{2} / \mathrm{kg}$ oil).

\section{Free fatty acids:-}

These acids were determined according to AOAC (1998) as grams oleic acid per 100 gram oil.

Specific absorbance at ultraviolet:-

The values of specific absorbance of oils at $K_{232}$ and $K_{270}$ were determined according to the method described by Kiritsakis (1991). To one gram of oil in $100 \mathrm{ml}$ volumetric flask, cyclohexane was added up to the mark then mixed vigorously. The absorbance was recorded at 232 and $270 \mathrm{~nm}$, respectively against pure cyclohexane as a blank. The following equation was used to calculate the specific absorbance:

$E^{1 \%}(\lambda)=\underline{A \lambda}$

$1 \mathrm{~cm}$

$$
C \times d
$$

Where:-

$\mathrm{E} \quad$ is the specific absorbance.

$\lambda \quad$ is the wave length used.

$A \lambda$ is the concentration at certain wave length

C is the concentration of sample solution $(\mathrm{g} / 100 \mathrm{ml})$

$D$ is the cell length in $\mathrm{cm}$.

\section{Fatty acid composition:-}

Fatty acid methyl esters of oil samples were prepared as described by Radwan (1978) in screw cap vial using $1 \% \mathrm{H}_{2} \mathrm{SO}_{4}$ in methanol under stream of nitrogen gas. The closed vials were heated in an oven at $90{ }^{\circ} \mathrm{C}$ min. Analysis of fatty acids was carried out by Shimadzu gas liquid chromatography (GLC-4 Cm,PYE) in Central Lab. Faculty of Agriculure, Alex. University, Alex.Egypt, using the following conditions:- Packing material ( SP- 
216), Solid support (Supelce port 801100$)$, column temperature $\left(130.3^{\circ} \mathrm{C}-\right.$ $190{ }^{\circ} \mathrm{C}$ ), 2C/min.rise, detector (Flame Ionization Detector), detector temperature $\left(250{ }^{\circ} \mathrm{C}\right)$, sheet speed $(5 \mathrm{~mm} / \mathrm{min})$, air flow rate $(0.5 \mathrm{ml} / \mathrm{min}), \mathrm{H}_{2}$ flow rate $(1 \mathrm{ml} / \mathrm{min}), \mathrm{N}_{2}$ flow rate $(30 \mathrm{ml} / \mathrm{min})$, sensitivity $10 \times 10^{-5}$.

\section{Fractionation of oil classes:-}

Oils were fractionated into different classes according to the method of Mangold and Malins (1960) using $20 \times 20 \mathrm{~cm}$ TLC plates coated with 0.25 $\mathrm{mm}$ thickness silica gel (Merk G,type 60) and developing solvent system consisted of petroleum ether $\left(40-60{ }^{\circ} \mathrm{C}\right)$ : diethyl ether: glacial acetic acid (70:30:2, v/v/v). The oil classes were visualized by exposing to iodine vapour in closed jar and cotton seed oil was used as a standard.

\section{Determination and separation of polyphenols :-}

\section{Extraction :-}

Method of Papadopouls and Boskou (1991) was applied to extract polyphenols from studied oils as follows:- Fifty grams of oil in $50 \mathrm{ml}$ hexane were extracted 3 times each with $30 \mathrm{ml}$ mixture of methanol: water $(60: 40 \mathrm{v} / \mathrm{v})$ in a blender. The combined extract was first filtered then concentrated near dryness under vacuum in a rotary evaporator at $40{ }^{\circ} \mathrm{C}$. The concentrated extract was dissolved in methanol and brought to $50 \mathrm{ml}$ in volumetric flask with methanol. This extract used for determination and separation of polyphenols and determination of antioxidant activity.

\section{Determination:-}

The total polyphenols content $(\mathrm{mg} / \mathrm{kg}$ oil) in the above extract was determined by folin ciocalteu colorimetric method according to AOAC (1998) using gallic acid as standard and spectronic 20 spectrophotometer at $760 \mathrm{~nm}$. Separation :-

The methanol extract of polyphenols was separated and fractionated on TLC prepared plate $(20 \times 20 \mathrm{~cm})$ coating with $0.25 \mathrm{~mm}$ thickness silica gel $\mathrm{G}$ (Merk) after one hour activation at $110^{\circ} \mathrm{C}$ (Fayad and Neeman, 1988). The developing solvent was consisted of the upper phase of benzene:glycial acetic acid:water (60:70:30)mixture. The visualization of polyphenols fractions was based on using iodine vapour (Mangold and Malins, 1960).

\section{Antioxidant activity:-}

Antioxidant activity was measured by the N,N-Dimethyl $-p$ phenylenediamine dihydrochloride (DMPD). Two hundred and nine mg of DMPD were dissolved in $10 \mathrm{ml}$ of deionized water. One $\mathrm{ml}$ of this solution was added to $100 \mathrm{ml}$ of $0.1 \mathrm{M}$ acetate buffer $(\mathrm{pH}=5.25)$ then $0.2 \mathrm{ml}$ of 0.05 $\mathrm{M}$ ferric chloride solution was added to obtain coloured radical cation $\left(\mathrm{DMPD}^{+}\right)$as follows:

DMPD (uncoloured) + oxidant $\left(\mathrm{Fe}^{3-}\right)+\mathrm{H}^{+} \rightarrow \mathrm{DMPD}^{+}$(purple coloured radical cation)

$\mathrm{DMPD}^{+}$((purple coloured radical cation) $+\mathrm{AOH}$ (antioxidant material) $\rightarrow \mathrm{DMPD}$ (uncoloured) $+\mathrm{AO}$ (antioxidant compouds)

One $\mathrm{ml}$ of this solution was directly placed in a $1 \mathrm{ml}$ plastic cuvette and its absorbance was measured at $505 \mathrm{~nm}$. Standard solution of the antioxidant compounds was prepared as follows: $0.1 \mathrm{~g}$ of ascorbic acid was dissolved in $100 \mathrm{ml}$ of deionized water to obtain $1 \mathrm{mg} / \mathrm{ml}$ of ascorbic acid. Antioxidant compounds were extracted from samples as follows: $1 \mathrm{ml}$ of polyphenol extract was added to $9 \mathrm{ml}$ methanol, then centrifuged at 12,000 
$\mathrm{xg}$ for $15 \mathrm{~min}$. A volume of $50 \mu \mathrm{l}$ of standard antioxidant or sample extraction was added in the spectrometric cuvette contained $1 \mathrm{ml}$ of DMPD+ solution, and after $10 \mathrm{~min}$ at $25 \stackrel{\circ}{\circ}$ under continuous stirring, the absorbance was measured at $505 \mathrm{~nm}$. Buffered solution was placed in the reference cuvette. A dose-response curve was derived for ascorbic acid, by plotting the absorbance at $505 \mathrm{~nm}$ as percentage of the absorbance of the uninhibited radical cation solution according to the following equation:

Inhibition of $A_{505}(\%)=\left(1-A_{F} / A_{0}\right) \times 100$

Where:

$A_{0}=$ Absorbance of uninhibited radical cation .

$A_{F}=$ Absorbance measured at $10 \mathrm{~min}$ after the addition of antioxidant samples. (Fogliano et al., 1999).

\section{Chlorophyll:-}

The content of chlorophyll ( $\mathrm{ppm}$ ) in olive oil was estimated as described in AOAC. (1998) by measuring the absorbance of olive oil at 360 , 670 and $710 \mathrm{~nm}$ using spectronic- 20 Spectrophtometer to calibrate and adjust the instrument to zero, carbon terta chloride was used as a blank. The cell containing the oil sample was heated to $30{ }^{\circ} \mathrm{C}$ in water bath before absorbance reading.

The following equation was used to calculate the chlorophyll:

Chlorophyll $(\mathrm{ppm})=\mathrm{OD}$ at $670-\left(\mathrm{OD} \frac{\text { at } 630+\mathrm{OD} \text { at } 710}{2}\right)$

Where $L=$ Cuvette length in $\mathrm{cm}$

$$
0.0964 \mathrm{~L}
$$

Technological methods:-

Oil / butter blend: -

Oil samples and butter were blended in food processor (at ratio 1:1 oil : butter ) until combined and had a thick cream consistency then packed into a small polystyrene bowl, covered with aluminum foil and placed in a refrigerator at $4{ }^{\circ} \mathrm{C}$ to firm (Mostafa, 2007).

\section{Carrot cake: -}

Oil samples, eggs and sugar were beaten in a mixer until obtaining a creamy texture. The dry ingredients were mixed in a separate bowl then added to the egg mixture and stirred until combined. The mixture was packed into a lightly greased baking pan and baked for about 35 minute at $350{ }^{\circ} \mathrm{C}$ in a baking oven. After cooling at room temperature, it was packed in aluminum foil (Mostafa, 2007).

\section{Sensory evaluation:-}

Colour, odour, taste and texture of the oil / butter blend and carrot cake were subjectively evaluated using 10 panelist of Food Science and Technology Department, Faculty of Agriculture, Alex. University, Egypt. Hedonic ranking test where $9=$ extremely acceptable to $1=$ extremely rejected as described by Kramer and Twigg (1970).

\section{Statistical analysis:-}

The present study was carried out in Randomized Complete Block design and Least Significant Difference at 0.05 probability level ( L.S.D 0.05 ) 
was used to compare the differences among treatment means according to Steel and Torrie (1984).

\section{RESULTS AND DISSCUSION}

\section{Identity characteristics:-}

The data in Table (1) shows some identity characteristics of olive oil $(\mathrm{OO})$, Avocado oil (AO) in addition to their blend (OAB). Generally, all these oils did not reveal any significant differences regarding saponification value and $\mathrm{K}_{232}$.In contrast, there were many significant differences could be traced with respect to colour, specific gravity, refractive index, iodine value, free fatty acids, peroxide value and $K_{270}$. Red colour was higher in OAB compared to $\mathrm{OO}$ and $\mathrm{AO}$, meanwhile yellow color was higher in $\mathrm{OO}$ and $\mathrm{OAB}$ compared to $A O$ but the latter had the highest value of blue colour followed by $O A B$ and $\mathrm{OO}$. These differences in the three colour fractions perhaps are attributed to the variation of pigments content such as polyphenols and chlorophyll. The $A O$ had the highest value of specific gravity and refractive index followed by $\mathrm{OAB}$ while $\mathrm{OO}$ tailed behind. Results in Table (1) also indicate that lodine value exhibited the highest value for $O O$ followed by $O A B$ and $A O$, respectively, This result agree with those of El-Refai et al. (2010) who mentioned that iodine value (IV) varies depending on the kind of oil, which indicate to the degree of saturation. $\mathrm{OO}$ had the highest peroxide value compared with $\mathrm{OAB}$ and $\mathrm{AO}$. Cuellar (1990) suggested the following standards for the olive oil, light yellow colour, $\leq 1.5 \%$ free fatty acids, $\leq 20$ milleq $\mathrm{O}_{2} / \mathrm{kg}$ peroxide value, $\leq 0.9 \mathrm{~K}_{270}$, and $184-196$ saponification value.

\section{Fatty acids composition:-}

The results in table (2) shows fatty acids composition of the three studied oils. These oils had considerable amounts of saturated fatty acids. It is worth to mention that $A O$ had the highest content of $C_{16: 0}(18.63 \%)$ followed by OAB (15.23\%) and $\mathrm{OO}(13.15 \%)$. Meanwhile $\mathrm{OO}$ had the highest amount of $\mathrm{C}_{18: 0}(4.01 \%)$ followed by OAB (3.26\%) and $\mathrm{AO}(2.42 \%)$. Studied oils had little amounts of $\mathrm{C}_{10: 0,}, \mathrm{C}_{12: 0}$ and $\mathrm{C}_{20: 0}$ and a relatively considerable amount of $\mathrm{C}_{14: 0}$. Furthermore, these oils contained high amounts of unsaturated fatty acids compared with saturated ones, especially $C_{18: 1}$ and $\mathrm{C}_{\text {18:2. }}$. The highest amount of oleic acid was found in $\mathrm{OO}$ followed by $\mathrm{OAB}$ and $A O$ in descending order, but $A O$ exhibited the highest amount of linoleic acid $\left(\mathrm{C}_{18: 2}\right.$ ) followed by $\mathrm{OAB}$ and finally $\mathrm{OO}$. The highest ratio between unsaturated and saturated fatty acids was figured out in $O O$ and $O A B$ followed by $\mathrm{AO}$, this means that $\mathrm{OO}$ and $\mathrm{AOB}$ had higher concentration of unsaturated fatty acid $(79.09 \%$ and $78.86 \%)$ compared to $\mathrm{AO}(76.59 \%)$ Boskou (1996) found that extra virgin olive oil had high proportion of monounsaturated fatty acids . i.e. oleic acid, , and a modest presence of polyunsaturated fatty acids and natural antioxidants, such as tocopherols, carotenoids, sterols, and phenolic compounds . Requejo et al. (2003) showed that avocado oil could be used as an ingredient in functional foods because of its high concentration of oleic acid, and substantial amounts of health beneficial compounds, such as antioxidants, vitamins and 
phytosterols. Meanwhile, Menendez et al. (2005) reported that oleic acid is present as a major constituent in avocado oil.

Table (1): Some identity characteristics of olive oil, avocado oil and their blend

\begin{tabular}{|c|c|c|c|}
\hline Characteristics & $\begin{array}{r}\text { Olive oil } \\
(00)\end{array}$ & $\begin{array}{c}\text { Avocado oil } \\
\text { (AO) }\end{array}$ & $\begin{array}{r}\text { Oil blend } \\
\text { (OAB) }\end{array}$ \\
\hline \multicolumn{4}{|l|}{ Colour } \\
\hline Red & $8.26^{b}$ & $8.03^{b}$ & $9.46^{a}$ \\
\hline Yellow & $29.40^{a}$ & $27.66^{b}$ & $29.42^{\mathrm{a}}$ \\
\hline Blue & $8.86^{c}$ & $11.66^{\mathrm{a}}$ & $10.33^{b}$ \\
\hline Specific gravity at $25^{\circ} \mathrm{C}$ & $1.4640^{c}$ & $1.4808^{a}$ & $1.4703^{b}$ \\
\hline Refractive index at $25^{\circ} \mathrm{C}$ & $0.9185^{b}$ & $0.9345^{a}$ & $0.9214^{b}$ \\
\hline lodine value & $86.74^{a}$ & $75.35^{c}$ & $80.68^{b}$ \\
\hline $\begin{array}{l}\text { Saponification value } \\
\text { ( } \mathrm{mg} \mathrm{KOH} / \mathrm{g} \text { oil) }\end{array}$ & $191.95^{a}$ & $195.51^{\mathrm{a}}$ & $191.16^{a}$ \\
\hline Free fatty acids (\%) & $0.28^{a}$ & $0.17^{\mathrm{b}}$ & $0.19^{b}$ \\
\hline Peroxide value & $3.66^{a}$ & $2.05^{b}$ & $2.23^{b}$ \\
\hline \multicolumn{4}{|l|}{$\begin{array}{l}\text { Specific absorbance } \\
\text { at ultraviolet }\end{array}$} \\
\hline $\mathrm{K}_{232}$ & $0.275^{a}$ & $0.248^{a}$ & $0.233^{a}$ \\
\hline $\mathrm{K}_{270}$ & $0.0843^{a}$ & $0.070^{\mathrm{b}}$ & $0.0830^{a}$ \\
\hline
\end{tabular}

Means in a row not sharing the same manuscript are significantly different at $P \leq 0.05$

Table (2): Fatty acid composition of olive, avocado oils and their blend.

\begin{tabular}{|c|c|c|c|}
\hline Fatty acid (\%) & $\begin{array}{l}\text { Olive oil } \\
(00)\end{array}$ & $\begin{array}{l}\text { Avocado oil } \\
\text { (AO) }\end{array}$ & $\begin{array}{r}\text { Oil blend } \\
(\mathrm{OAB})\end{array}$ \\
\hline \multicolumn{4}{|l|}{ Saturated fatty acids } \\
\hline$\overline{\mathrm{C}_{10: 0}}$ & 0.69 & --- & 0.31 \\
\hline $\mathrm{C}_{12: 0}$ & 0.57 & 0.64 & 0.50 \\
\hline $\mathrm{C}_{14: 0}$ & 1.18 & 1.72 & 1.32 \\
\hline$C_{16: 0}$ & 13.15 & 18.63 & 15.23 \\
\hline $\mathrm{C}_{18: 0}$ & 4.01 & 2.42 & 3.26 \\
\hline $\mathrm{C}_{20: 0}$ & 1.31 & --- & 0.52 \\
\hline Total & 20.91 & 23.41 & 21.14 \\
\hline \multicolumn{4}{|l|}{ Unsaturated fatty acids } \\
\hline$\overline{\mathrm{C}_{16: 1}}$ & 1.52 & 4.49 & 3.14 \\
\hline$C_{18: 1}$ & 67.50 & 57.64 & 62.16 \\
\hline $\mathrm{C}_{18: 2}$ & 10.07 & 14.46 & 13.56 \\
\hline Total & 79.09 & 76.59 & 78.86 \\
\hline Unsaturated: Saturated & $3.78: 1$ & $3.27: 1$ & $3.73: 1$ \\
\hline
\end{tabular}


Polyphenols, chlorophyll and antioxidant activity:-

Data in Table (3) show the polyphenols and chlorophyll contents along with antioxidant activity of $\mathrm{OO}, \mathrm{AO}$ and $\mathrm{OAB}$. Data revealed significant differences among the three studied oils regarding each of polyphenols, chlorophyll and antioxidant activity, whereas $\mathrm{OO}$ contained the highest value of polyphenols followed by $\mathrm{OAB}$ and $\mathrm{AO}$. Meanwhile, chlorophyll content was found to be the highest in $A O$ compared with $O A B$ and $O O$. The relatively high content of polyphenols and chlorophyll in each of the three oils investigated here reflected considerable percentage of antioxidant activity in such oils, whereas $\mathrm{OO}$ possessed the highest antioxidant activity $(68.2 \%)$ followed by OAB (61.0\%) then AO (53.7\%). Interesse et al. (1971) showed that chlorophyll and pheophytin had a prooxidant effect on lipids in the presence of light, and acted as antioxidant in dark. Endo et al. (1985) found that the antioxidant effect of chlorophyll and pheophytins were depended on the storage temperature. Chlorophyll (a) had the strongest antioxidant activity, followed by chlorophyll (b). Baldioli et al. (1996) found that virgin olive oil contains a number of substances which elongate its shelf-life. Amongst them, phenolic compounds are the ones that mainly determine a greater resistance to auto-oxidation. Boskou (1996) reported that olive oil contains natural antioxidants such as tocopherols, carotenoids, sterols and phenolic compounds that represent $27 \%$ of the unsaponifiable fraction . Teissedre and Waterhouse (2000) and Koski et al.(2002) reported that olive oil has been established more stable than other vegetable oils to thermal degradation due to its high amount of mono unsaturated fatty acids (MUFA) and to the content of phenolic compounds.

Table(3): Polyphenols, chlorophyll and antioxidant activity of olive, avocado oils and their blend.

\begin{tabular}{llll} 
Component & $\begin{array}{l}\text { Olive oil } \\
\text { (OO) }\end{array}$ & $\begin{array}{l}\text { Avocado oil } \\
\text { (AO) }\end{array}$ & $\begin{array}{l}\text { Oil blend } \\
\text { (OAB) }\end{array}$ \\
\hline Polyphenols $(\mathrm{mg} / \mathrm{kg})$ & $176.07^{\mathrm{a}}$ & $10.51^{\mathrm{c}}$ & $96.28^{\mathrm{b}}$ \\
Chlorophyll $(\mathrm{mg} / \mathrm{kg})$ & $14.91^{\mathrm{c}}$ & $73.45^{\mathrm{a}}$ & $4637^{\mathrm{b}}$ \\
Antioxidant activity $(\%)$ & $68.20^{\mathrm{a}}$ & $53.70^{\mathrm{c}}$ & $61.00^{\mathrm{b}}$
\end{tabular}

Means in a row not sharing the same manuscript are significantly different at $P \leq 0.05$

\section{Oil classes:-}

Fig (1) illustrates separation of olive, avocado, oils and their blend by TLC charomatogram, the main class in them was triacylglycerols, the other classes which were detected in considerable quantities were polar lipids, monoacylglycerols, 1,2 and 2,3 diacylglycerols, free steroids, 1,3diacylglycerols, hydrocarbons, esters and traces from free fatty acids. Gamel (1995) found that most of the fatty acids of olive oil are present as triglycerides and the non- glycerides fraction of olive oil contain non-glyceride 
fatty acid esters, hydrocarbons, sterols, phospholipids, chlorophyll and flavour compounds.

\section{Polyphenols separation: -}

Fig (2) shows the separation of polyphenols from the three studied oils, (AO, OO and OAB) by TLC method. From the chromatogram, it could be noticed that, there were six compounds of polyphenols could be separated from AO. Meanwhile, nine compounds of polyphenols were separated from $\mathrm{OO}$ and $\mathrm{OAB}$. These results indicated that, $\mathrm{OO}$ contained more compounds of polyphenols compared with $A O$ and this was reflected in polyphenols content in OAB which contained the same components found in the two oils.

\section{Carrot cake and oil / butter blend products:-}

Table (4) shows results of the organoleptic evaluation of carrot cake and oil/butter blend using $\mathrm{OO}, \mathrm{AO}$ and $\mathrm{OAB}$. Data of organoleptic evaluation indicated that, all organoleptic properties of the two products were quite accepted. There are significant differences between some organoleptic properties such as colour and taste in carrot cake and oil/butter blend, whereas the colour and taste for carrot cake produced from $O O$ and $O A B$ were more accepted comparing to that produced from $A O$. Meanwhile colour and taste of oil /butter blend made from $A O$ and $O A B$ were more accepted comparing with that made from $\mathrm{OO}$. Other organoleptic properties of the two products did not show any significant differences and they were quite accepted as judged by panelists. Fig. (3) shows oil / butter blend and carrot cake which were made in the present study.

Result in our study confirm the encouragement of avocado cultivation in Egypt due to a high nutritional value of it's oil.

Table (4) : Organolyptic evaluation of oil / butter blend and carrot cake processed from studied oils

\begin{tabular}{|c|c|c|c|c|c|c|c|c|c|c|}
\hline \multirow[t]{2}{*}{ Oils } & \multicolumn{5}{|c|}{ Carrot cake } & \multicolumn{5}{|c|}{ Oil /butter blend } \\
\hline & Taste & Odour & Texture & Acceptability & Colour & Taste & Odour & Texture & Accept & bility Colour \\
\hline $\begin{array}{l}\text { Olive } \\
\text { oil }\end{array}$ & $6.5^{\mathrm{a}}$ & $7.5^{\mathrm{a}}$ & $7.7^{\mathrm{a}}$ & $7.6^{\mathrm{a}}$ & $7.7^{\mathrm{a}}$ & $6.3^{b}$ & $6.6^{\mathrm{b}}$ & $7.8^{\mathrm{a}}$ & $7.2^{\mathrm{a}}$ & $7.2^{\mathrm{a}}$ \\
\hline $\begin{array}{l}\text { Avocado } \\
\text { oil }\end{array}$ & $6.4 \mathrm{~b}$ & $6.7^{b}$ & $8.0^{\mathrm{a}}$ & $7.3^{\mathrm{a}}$ & $8.1^{\mathrm{a}}$ & $7.6^{a}$ & $7.5^{\mathrm{a}}$ & $7.8^{\mathrm{a}}$ & $7.6^{\mathrm{a}}$ & $7.8^{\mathrm{a}}$ \\
\hline $\begin{array}{l}\text { Blend } \\
\text { oil }\end{array}$ & $7.5^{\mathrm{a}}$ & $8.3^{\mathrm{a}}$ & $8.1^{\mathrm{a}}$ & $7.6^{a}$ & $8.3^{\mathrm{a}}$ & $6.9^{\mathrm{ab}}$ & $7.0^{\mathrm{a}}$ & $7.6^{\mathrm{a}}$ & $7.0^{\mathrm{a}}$ & $7.7^{\mathrm{a}}$ \\
\hline
\end{tabular}

Means in a column not sharing the same manuscript are significantly different at $P \leq 0.05$ 


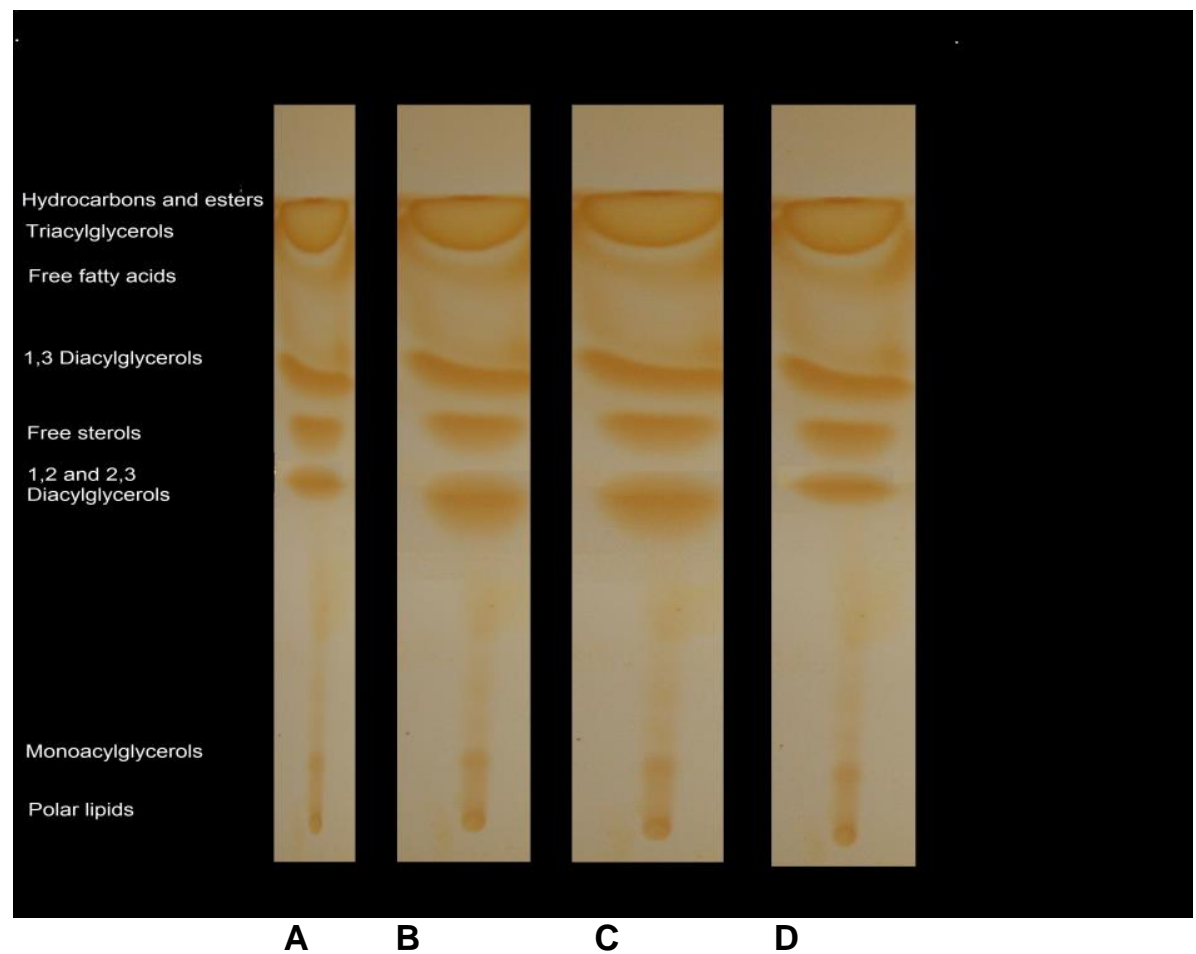

Figure (1): The TLC chromatogram, for oil classes of olive, avocado oils
A: Cotton seed oil
B: Olive oil
C: Avocado oil
D: Oil blend 


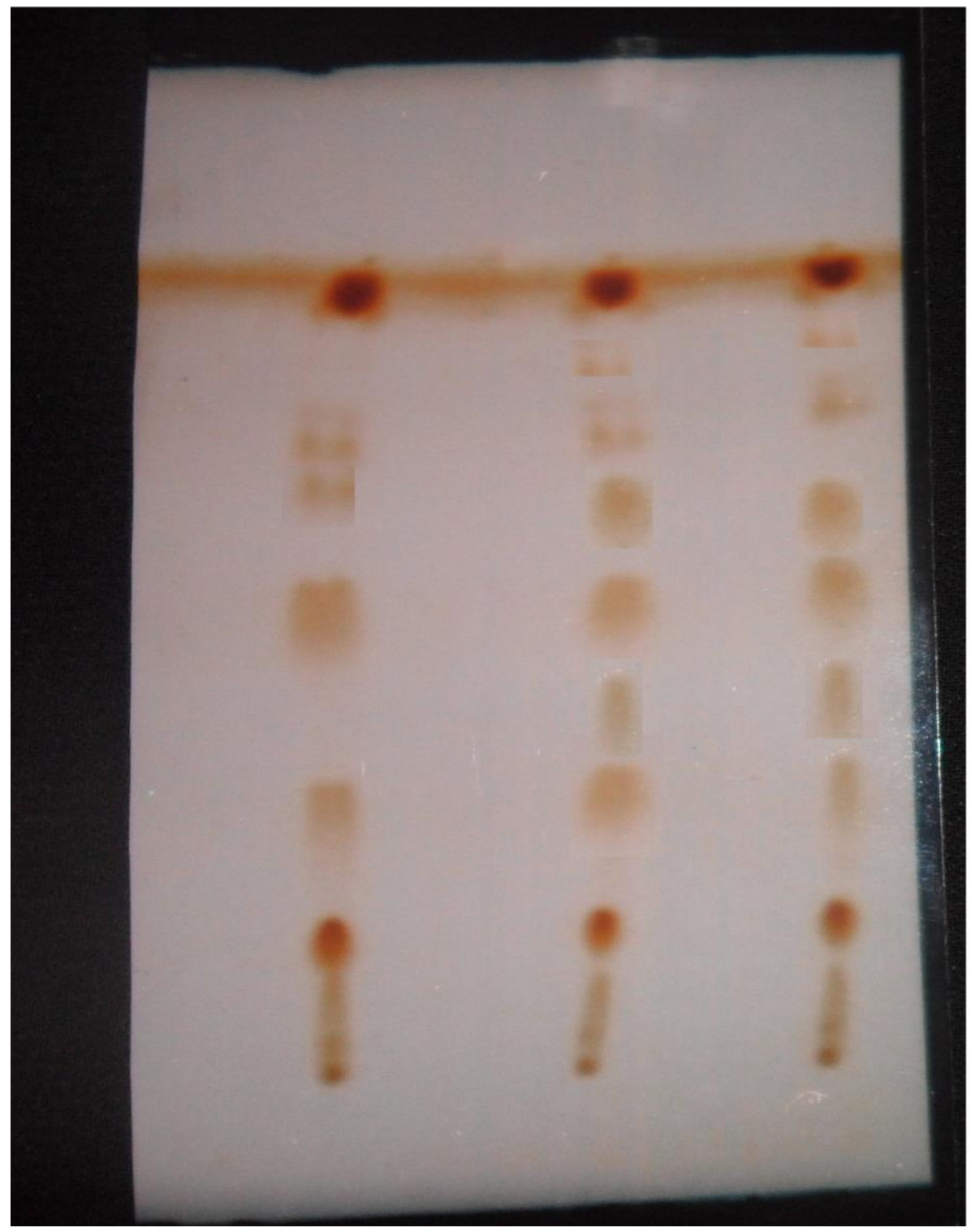

A

B

C

Figure (2): The TLC chromatogram for phenolic compounds of olive, avocado oils and their blend

A: Avocado oil

B: Olive oil

C: Oil blend 


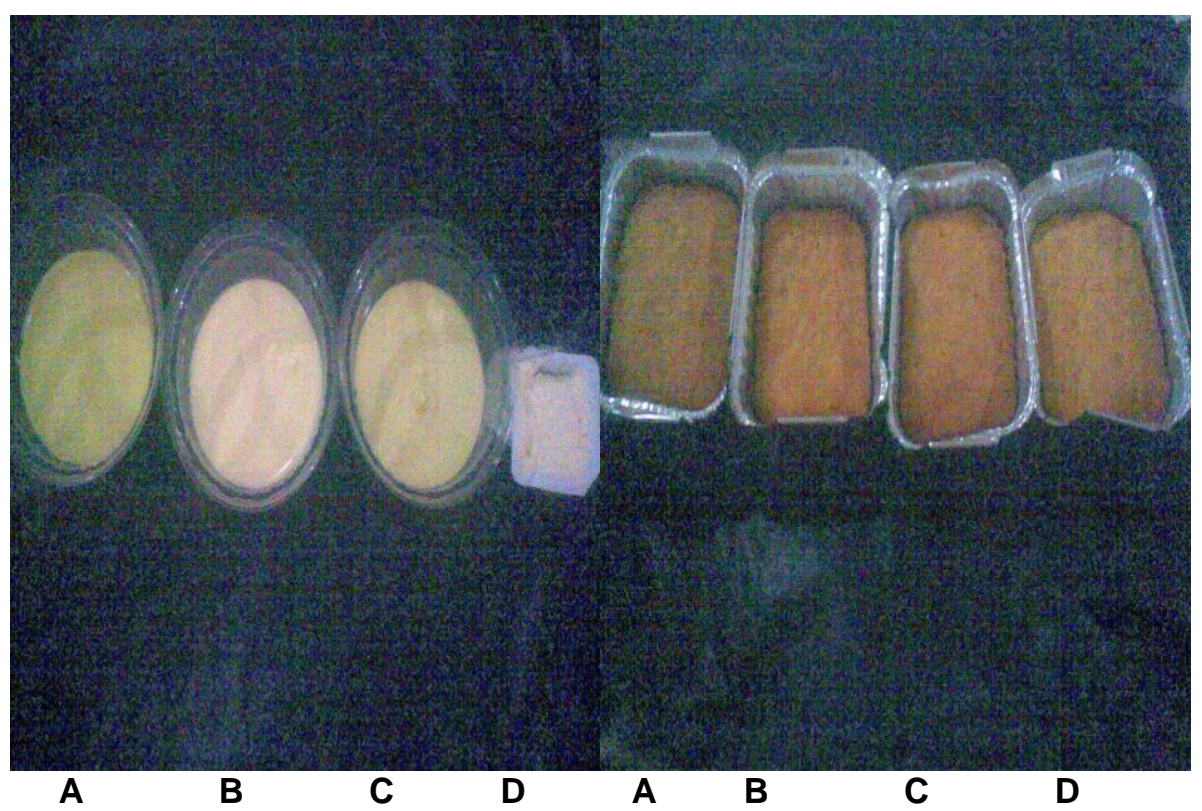

Oil / butter blend

Carrot cake

Fig (3): Oil / butter blend and carrot cake containing olive, avocado oils and their blend at $1: 1$ ratio

A: Product from avocado oil

B: Product from olive oil

C: Product from oil blend

D: Control sample

\section{REFERENCES}

Alvarenga,N. and Ferro, E.A.(2005).Bioactive triterpenes and related compounds from Celastraceae. Bioactive Natural Products (Part K), 30: 635-702.

Angerosa ,F. ; Mostallino, R.; Basti ,C.;Vito, R. (2000). Alvarenga, N. and Ferro, E. A.(2005). Bioactive triterpenes and virgin olive oil odour notes: their relationship with volatile compounds from the lipoxigenase pathway and secoiridoid compounds. FoodChem.,68: 283-287 .

Anonymous. (2000). FAO production yearbook. Rome. Bergh, B. (1992).Nutritious value of avocado (pp.123-135). CA: California Avocado Society Book.

A.O.A.C.(1998). Association of Official Analytical Chemists. Official methods of analysis of the Association of Official Analytical Chemists, Washington,4,DU,USA.

Azadmard-Damirchi, S.; Savage, G. P.; and Dutta, P. C. (2005). Sterol fractions in hazelnut and virgin olive oils and 4, 4'- dimethylsterols as possible markers for detection of adulteration of virgin olive oil. J. Am. Oil Chem. Soc., 82: 717-725. 
Baldioli, M.; Servili, M.;Perretti, G. and Montedoro, G. F. (1996). Antioxidant activity of tocopherols and phenolic compounds of virgin olive oil. J. Am. Oil Chem. Soc., 73: 1589-1593.

Bergh, B. (1992). Nutritious value of avocado CA: California Avocado Society Book. pp. 123-135.

Berger, A.; Jones, P. and Abumweis, S. (2004). Plant sterols: factors affecting their efficacy and safety as functional food ingredients. Lipids in Health and Disease, 3: 5-12.

Boskou, D.(1996) Olive oil composition. In: Boskou D, editor. Olive oil: chemistry and technology. Champaign, Illinois: AOCS Press,:52- 83.

Chan, K. (2005). Greasing on innovation and discovery. Asia Pacific Food Industry, Pescara, Italy, 82-84.

Cuellar, L.R. (1990). Olive oil quality improvement. Istituto Sperimental Per la Elaiotecnia.

Darmon, N.; Darmon, M. and Ferguson, E. (2006). Identification of nutritionally adequate mixtures of vegetable oils by linear programming. J. Hum Nutr. Diet.,19: 59-69.

Egan,H.; Kirk,R. and Sawyer,R.(1987).Pearson's Chemical Analysis of Food. $8^{\text {th }}$ ed., Churchill, Livingstone, UK .

El-Refai,A.A.; El-Borai, N.A. and Said, A.(2010). Preparation of valuable oil blends with desired qualities. Proceeding of The Second International Conference in Food Industries and Biotechnology and the Associated Fair. pp. 278-290.

Endo, Y.; Usuki , P. and Kaneda,T.(1985) . Antioxidant effects of chlorophyll and pheophytin on the autoxidation of oils in the dark.1.Composition of the inhibitory effects. J. Am. Oil.Chem. Soc., 62: 1375-1378.

Fayad, Z. and Neeman, I. (1988). Separation and concentration of natural antioxidants from the rape of olives. J.Am.Oil Chem Soc., 65:990-993.

Fogliano,V.; Verde,V.; Randazzo,G.and Ritieni, A. (1999) . Method for measuring antioxidant activity and its application to monitoring the antioxidant capacity of wines. J. Agric. Food Chem., 47:1035-1040

Frega, N., Bocci, F., Lercker, G., and Bortolomeazzi, R. (1990) Lipid composition of some avocados cultivars. International J. Food Sci.,3: 197-204.

Galli,C. and Visioli,F.(1999).Antioxidant and other activities of phenolics in olives/olive oil, typical components of the Mediterranean diet. Lipids .34: $23-26$.

Gamel, T.H.A. (1995). Effect of Phenolic Extracts From Rosemary Plant and Vegetable Water on the Stability of Blend Olive Oil and Sunflower Oil. M.Sc.Thesis, Mediterranean Agronomic Institute of China, Greece.

Gordon ,M.H.; Paiva- Martins,F.and Almeida, M.(2001).Antioxidant activity of hydroxytyrosol acetate compared with that of other olive oil polyphenols. J Agric. Food Chem.,49: 2480-2485.

Interesse, F.A.; Ruggiero, P. and Vitagliano, M.(1971). Autoxidation of olive oil. Effect of chlorophyll pigments. Ind. Agrarie., 9:318-322.

Kiritsakis, A.K. (1991). Olive Oil. JAOCS press.Champaign, Illinois, USA. 
Koski, A.; Psomiadou, E.;Tsimidou, M.; Hopia, A.; Kefalas, P. and Wahala, K. (2002).Oxidative stability and minor constituents of virgin olive oil and cold-pressed rapeseed oil. European Food Research and Technology, 214: 294-298.

Kramer, A. and Twigg, B.A. (1970). Quality control for the food industry $3^{\text {th }}$. AVI Publishing Co. Westport Conn. London. England.

Makinney,G. and Little , A. (1962). Colour of Food. The AVI Publishing Company.INC.

Mangold, H.K. and Malins, D.C. (1960) . Fractionation of fats, oils an waxes on thin layers of silica acid. J.Am.Oil Chem.Soc.,37: 383- 385.

Menendez, J. A.; Vellon, L.;Colomer, R., and Lupu, R. (2005). Oleic acid the main mono unsaturated fatty acid of olive oil suppresses Her-2/neu (erbB-2) expression and synergistical enhances the growth inhibitory effects of trastuzumat (Herceptin) in breast cancer cells with Her2 /neu oncogene amplification. Annals of Oncology, 16: 359-371.

Mostafa, R.A.E.(2007). Preparation, Characterization and Utilization of Vegetable Oil Blends Rich in Omega-3 and -9 Fatty Acids Ph.D. Thesis.Food Seince and Thechnology, Dept.Faculty of agric.Alex.Univ. Egypt.

Papadopouls, G. and Boskou, D . (1991). Antioxidant effect of natural phenols on olive oil. J.Am. Oil Chem. Soc.,68:669-671.

Radwan,S.S.(1978).Coupling of two dimensional thin layer chromatography with gas chromatography for the quantitative analysis of lipids classes and their constituent fatty acids.J. Chrom. Sci., 16:538-542.

Requejo, A. M.; Ortega, R. M.; Robles, F.; Navia, B., Faci, M., and Aparicio, A. (2003). Influence of nutrition on cognitive function in a group of elderly, independently living people. European Journal of Clinical Nutrition, 57: 54-57.

Steel, J.D. and Torrie , J.H.(1984). Principles and Procedures of Statistics.A.Biometrical Approach. Mc Graw Hill. $4^{\text {th }}$ Priniting,New York.USD

Teissedre, P. L. and Waterhouse, A. L. (2000). Inhibition of oxidation of human low density lipoproteins by phenolic substances in different essential oils varieties. J. Agric. Food Chem., 48: 3801-3805.

Uccella, N. (2001) Olive biophenols: novel ethnic and technological approach: A review. Trends Food Sci. Tech.,11:328-329

Woolf, A.; Wong, M.; Eyres, L.; McGhie, T.; Lund, C. and Olsson, S.(2008). Avocado oil. In R. A. Moreau and A. Kamal-Eldin (Eds.), Gourmet and health-promoting specialty oils.Urbana: AOCS Monograph Series on Oil Seeds. (pp. 73- 125). 
زيـت الزيتـون و زيـت الأفوكـادو و مخلوطهمـا: تقييمهـا و اسـتخدامها فـى بعض

الأغذية

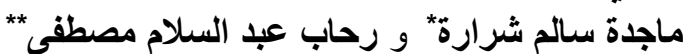

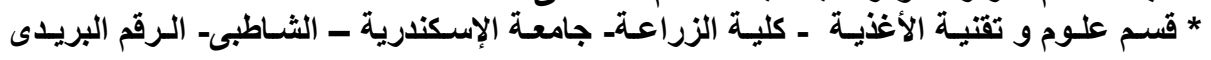

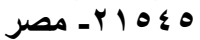

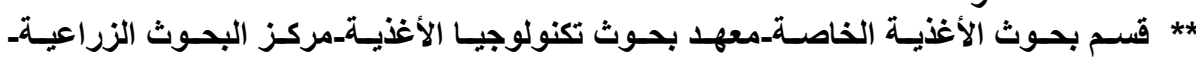

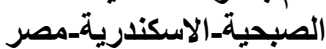

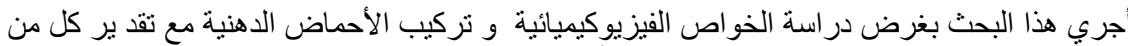

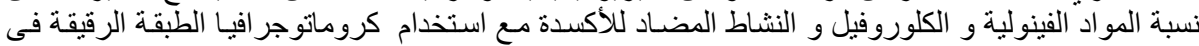

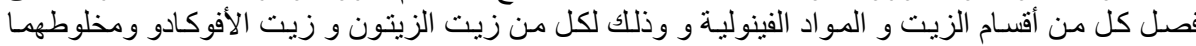

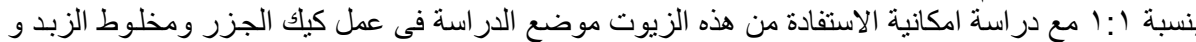

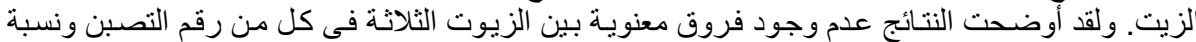

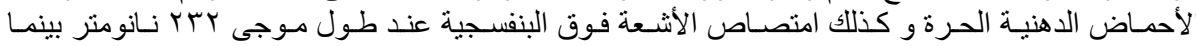

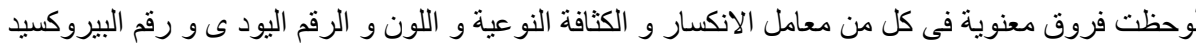

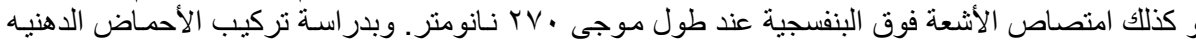

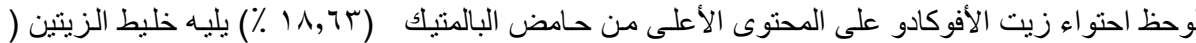

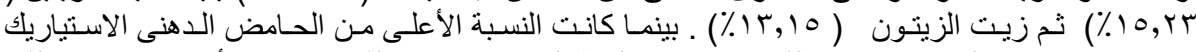

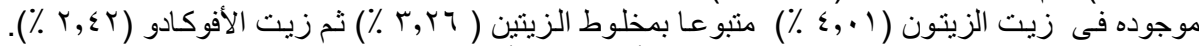

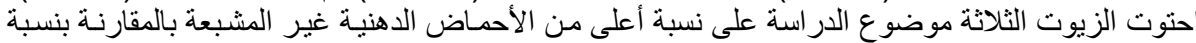

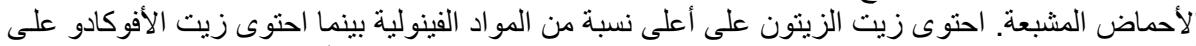

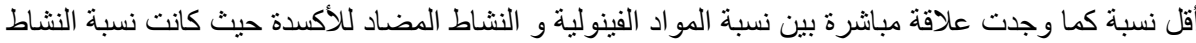

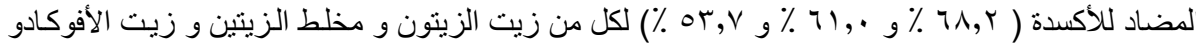

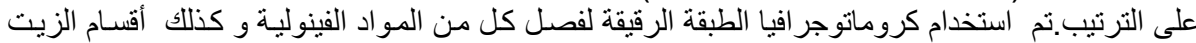

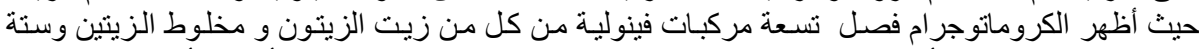

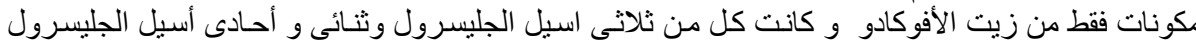

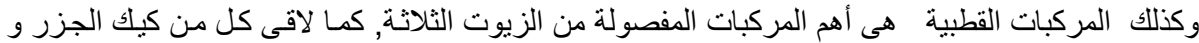

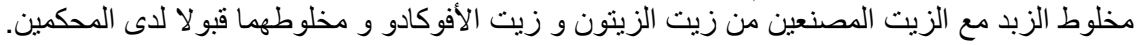

كلية الزراعة - جامعة المنصورة كلية الزراعة - جامعة الأسكندرية

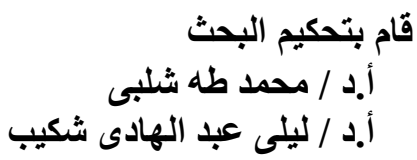


Sharara, Magda S. and Rehab A. E. Mostafa 
J. Food and Dairy Sci., Mansoura Univ., Vol. 3 (7): 367 - 381, 2012 
J. Food and Dairy Sci., Mansoura Univ., Vol. 3 (7): 367 - 381, 2012 

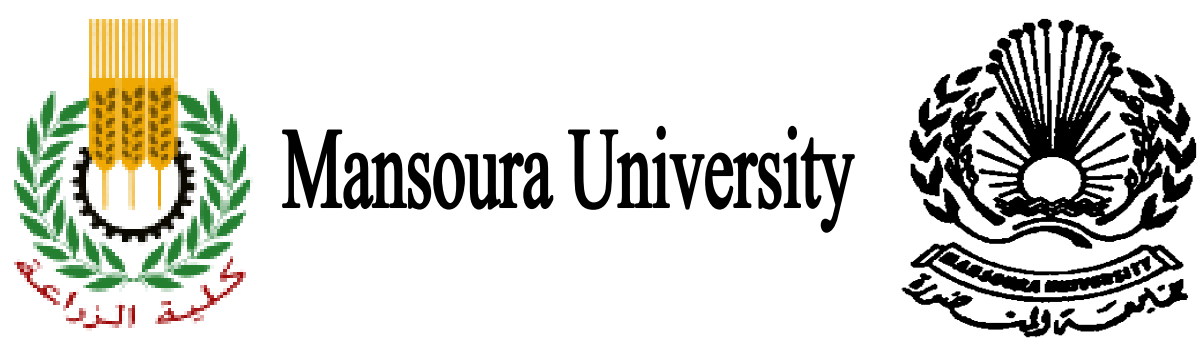

ISSN $2090-3650$

Reprint from

\title{
Journal of
}

\section{Food and Dairy Sciences}

\author{
Volume 3 No. (7), July, 2012
}

Established in 1976

Official Publication of Faculty of Agriculture, Mansoura University 

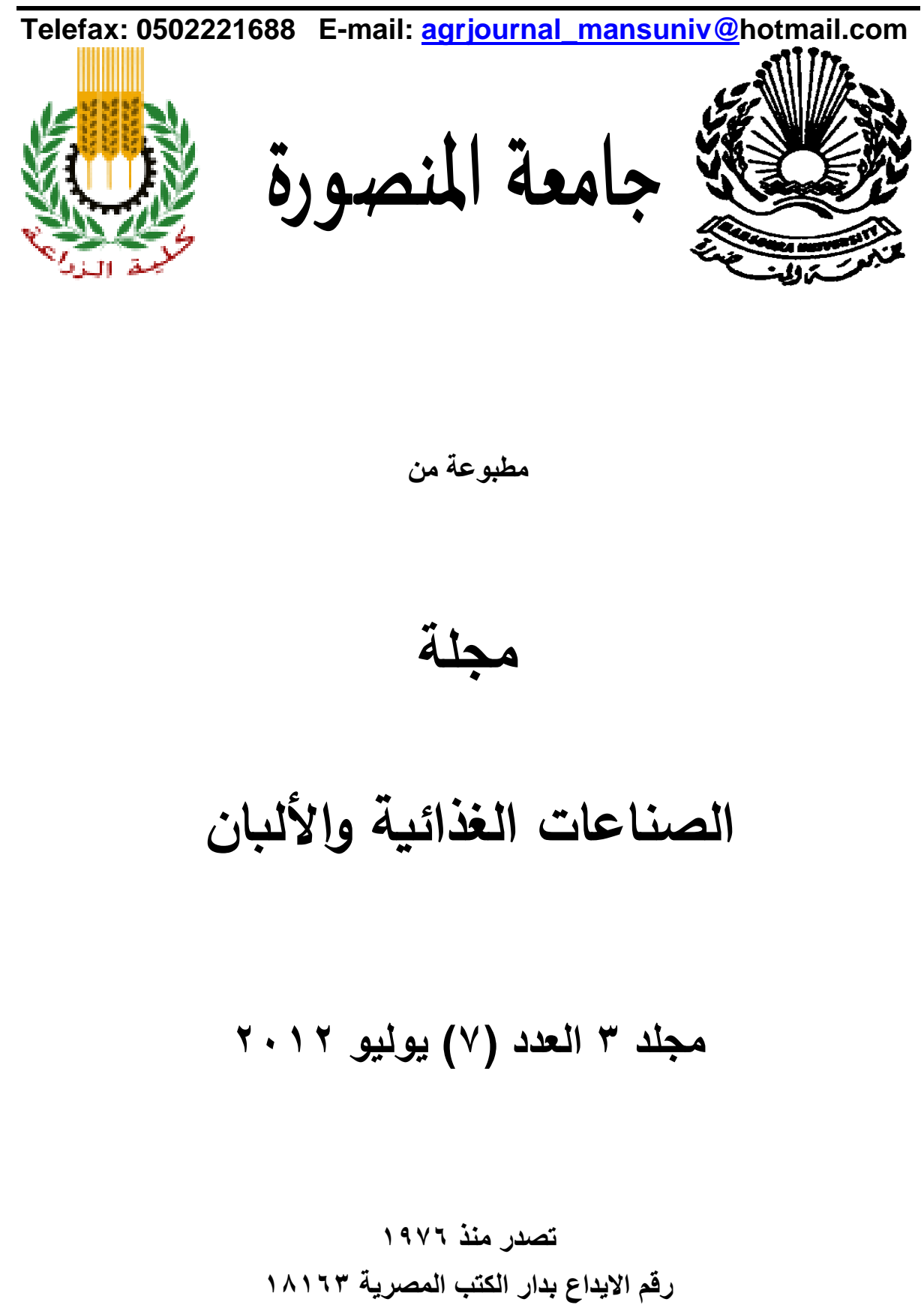